\title{
A proline-rich peptide originating from decomposing mangrove leaves is one natural metamorphic cue of the tropical jellyfish Cassiopea xamachana
}

\author{
J. Fleck ${ }^{1, *}$, W. K. Fitt ${ }^{2}$, M. G. Hahn ${ }^{3}$ \\ ${ }^{1}$ Lehrstuhl für Spezielle Zoologie, Ruhr-Universität, D-44780 Bachum, Germany \\ ${ }^{2}$ Institute of Ecology, University of Georgia, Athens, Georgia 30602-2602, USA \\ ${ }^{3}$ Complex Carbohydrate Research Center, University of Georgia, Athens, Georgia 30602-4712, USA
}

\begin{abstract}
Planula larvae of the scyphozoan Cassiopea xamachana settle and metamorphose on degrading mangrove leaves of Rhizophora mangle that lie submerged in shallow water mangrove ecosystems. Our prior study (Fleck \& Fitt 1999; J Exp Mar Biol Ecol 234:83-94) indicated that marine bacteria are involved in the release of at least 1 peptidic compound from such leaves. The goal of our present study was to isolate and purify at least 1 natural peptidic cue originating from deteriorating leaves by means of ultrafiltration, gel filtration and reversed phase HPLC and subsequently obtain characteristic data of this cue. The ultrafiltrate $(\leq 10 \mathrm{kD})$ of the homogenate of decaying mangrove leaves was subjected to gel filtration on a Sephadex G 25 column, resulting in 3 fractions which were tested for their capacity to induce metamorphosis of planula larvae in bioassays performed in the laboratory. Fraction I $(\geq 5 \mathrm{kD}$ ) was most effective in inducing metamorphosis of $75 \%$ of planulae at $1 \mathrm{mg}$ freeze-dried material ml $\mathrm{m}^{-1}$ seawater within $24 \mathrm{~h}$. Fractions II and III (both $\leq 5 \mathrm{kD}$ ) resulted in metamorphosis of only $1 \%$ of larvae or less within $72 \mathrm{~h}$ when applied at $5 \mathrm{mg} \mathrm{m}^{-1}$ Isochratic HPLC separation of Fraction I with $24 \%$ methanol yielded 2 biologically active fractions. One fraction $(A / B)$, which induced $47 \%$ of the larvae to metamorphose at $0.9 \mathrm{mg}$ lyophilized material ml $\mathrm{m}^{-1}$ seawater within $24 \mathrm{~h}$, consisted of a mixture of at least 2 subfractions and was not further analyzed. The other fraction (C) effected metamorphosis of $85 \%$ of larvae at a concentration of $0.5 \mathrm{mg} \mathrm{m}^{-1}$ within $24 \mathrm{~h}$. Matrix-assisted laser desorption ionization (MALDI) mass spectrometry of this fraction revealed a molecular weight of approximately $5.8 \mathrm{kD}$. Automated amino acid analysis showed that Fraction $C$ was rich in proline (ca $44 \%$ ) and glycine residues (ca $16 \%$ ), corresponding to characteristic proline-rich cell wall proteins of plants. Automated sequencing of the natural inducer failed due to a blocked amino terminus. The results of our present study suggest that metamorphic inducers for $C$. xamachana may emerge nonspecifically as a byproduct of bacterial degradation of deteriorating, proteinaceous plant tissue in their habitat.
\end{abstract}

KEY WORDS: Natural metamorphic inducer $\cdot$ Cnidaria $\cdot$ Peptides $\cdot$ Settlement $\cdot$ Scyphozoa $\cdot$ Mangrove leaves Proline-rich proteins

\section{INTRODUCTION}

Inducers of marine invertebrate larvae metamorphosis have become a useful tool for studying possible signal transduction mechanisms underlying initiation of larval settlement and recruitment. Most researchers in this field have used artificial triggers to obtain informa-

•E-mail: juergen.fleck@ruhr-uni-bochum.de tion about the small steps involved in a complex network of signal transmissions in larval cells (for review see Pawlik 1992, more recent papers by e.g. Pechenik et al. 1995, Wendt \& Woolacott 1995, Hassel et al. 1996, Henning et al. 1996, Walther et al. 1996, Woolacott \& Hadfield 1996, McCauley 1997, Thomas et al. 1997, Berking 1998, Carpizo-Ituarte \& Hadfield 1998, Pechenik \& Qian 1998, Froggett \& Leise 1999). During the past decade a number of studies have focussed on 
the identification of natural metamorphic cues in an attempt to test whether models established in the laboratory may work in nature, as well as to explain distribution of individuals in certain specific habitats (e.g. Hadfield \& Pennington 1990, Morse \& Morse 1991, Tamburri at al. 1992, Leitz \& Wagner 1993, Rittschof 1993, Gibson 1995, Forward et al. 1996, Lambert et al. 1997. Walters et al. 1997, Wieczorek \& Todd 1997. Avila 1998). However, progress has been slow, and to date most cues originating from substrata in the environment have only been partially characterized (e.g. Morse \& Morse 1991, Pawlik 1992, Leitz \& Wagner 1993, Zimmer-Faust \& Tamburri 1994, Lambert et al. 1997).

At present, the exact chemical structure of only a few naturally occuring metamorphic inducers of marine invertebrate larvae has been determined. Urochordamine A, a compound found in a lipophilic extract of the tunic of the tunicate Ciona savignyi, induced metamorphosis of its larvae in laboratory experiments (Tsukamoto et al. 1993). Diterpenoid chromanols extracted from brown algae of the family Sargassaceae were shown to effect metamorphosis of the hydroid Coryne uchidai (Kato et al. 1975). Bonellin, an alkylated chlorin isolated from the female proboscis of the echiurid Bonellia viridis, induced masculinisation of larvae of the same species (Pelter et al. 1978, Jaccarini et al. 1983). Larvae of the bivalve Pecten maximus were reported to metamorphose in response to Jacaranone, a compound isolated from the red alga Delesseria sanguinea (Yvin et al. 1985). However, some of the findings reported above are not absolutely conclusive and the role of these substances as natural inducers remains questionable (see also the critical review by Pawlik 1992).

A variety of free fatty acids originating from the sand of the tubes of the polychaete Phragmatopoma lapidosa lapidosa (western Atlantic) and Phragmatopoma lapidosa californica were shown to trigger settlement of their larvae (Pawlik 1986, 1988, Pawlik \& Faulkner 1986). Contradictory results were presented by other researchers (Jensen \& Morse 1984, 1990, Jensen et al. 1990). These examples show the difficulties underlying the isolation and characterization of natural metamorphic inducers once the natural source of the cues has been elucidated: they have to be accessible for isolation, they have to be purified from a huge variety of sometimes chemically overlapping substances, and they have to be subjected to suitable and unambiguous methods of characterization with only small amounts of the natural cue often available. Finally it has to be demonstrated that the identified and fully characterized inducer is naturally released, i.e. the results obtained in the laboratory can be transferred into the field.
Research into cnidarians has shown a variety of settlement inducers. As reported above diterpenoid chromanols induce planula larvae of the hydroid Coryne uchidaj to settle on brown algae of the family Sargassaceae (Nishihira 1968, Kato et al. 1975). A lipid originating from the marine bacterium Alteromonas espejiana was shown to trigger metamorphosis of $\mathrm{Hy}$ dractinia echinata (Hydrozoa; Leitz \& Wagner 1993). This bacterium covers mollusc shells inhabited by the crab Eupargurus sp. that are occupied by colonies of Hydractinia echinata (Müller 1969, Leitz \& Wagner 1993). Larvae of another cindarian, the scleractinian coral Agaricia humilis Anthozod, metamorphose upon contact with crustose coralline red algae (Morse et al. 1988). The chemical nature of this natural cue was shown to be a complex carbohydrate associated with the cell walls of Hydrolithon boergesenii or its associated microflora (Morse \& Morse 1991).

Synthetic oligopeptides were the first artificial compounds found to trigger metamorphosis of the scyphozoan Cassiopea spp. (Fitt \& Hofmann 1985). Laboratory experiments showing that bacterial cleavage of the proteins collagen and casein resulted in biologically active fragments provided the basis for the hypothesis that in nature marine bacteria may be involved in the production of metamorphic inducers by degradation of biogenic substrata like some species of marine algae (Hofmann et al. 1978, Neumann 1979, Hofmann \& Brand 1987). Very recent findings support this hypothesis. Larvae of $C$. xamachana were found to settle on black, decomposing leaves of the red mangrove $R h i$ zophora mangle in the environment but not on newly fallen green or red leaves (Fitt 1991, Fitt \& Costley 1998, Fleck \& Fitt 1999). One natural cue originating from these leaves was crudely characterized as at least 1 water-soluble peptide smaller than $12 \mathrm{kD}$ (Fleck \& Fitt 1999). Marine bacteria were found to be involved in the production of this inducer (Fleck \& Fitt 1999).

In the present study we show that a peptide, most likely derived from the cell walls of decomposing parts of plants, can serve as a natural metamorphic cue for cnidarian larvae. We provide the molecular weight and the amino acid composition of one such compound originating from degrading mangrove leaves of $R h i$ zophora mangle that induces larvae of Cassiopea Xamachana to settle and metamorphose.

\section{MATERIAL AND METHODS}

Cassiopea xamachana. Eggs from brooding female medusae of Cassiopea xamachana were collected directly in a shallow lagoon in Grassy Key, Florida Keys, Florida, USA. The eggs were transferred to glass dishes in the laboratory containing seawater with anti- 
biotics (ABS, $100 \mathrm{mg}$ penicillin, $100 \mathrm{mg}$ neomycin and $130 \mathrm{mg}$ streptomycin dissolved in $1 \mathrm{l}$ of artificial seawater [Instant Ocean], salinity 35 ppt). All larvae hatched within $3 \mathrm{~d}$ and were transferred to a clean dish with fresh ABS afterwards.

Preparation of leaf homogenate. A total of 210 submerged, dark and degrading leaves of Rhizophora mangle were collected in a lagoon inhabited by Cassiopea xamachana in Grassy Key. The leaves were wiped of debris. Fractions of 30 leaves each were cut into small pieces with a razor blade on ice and transferred to $80 \mathrm{ml}$ ice-cold distilled water. The fragments were then homogenized with a Polytron (Brinkmann Instruments) on ice. The homogenate was centrifuged for $5 \mathrm{~min}$ at $24000 \times \mathrm{g}$ at $4^{\circ} \mathrm{C}$. Supernatant and pellet were separated.

Ultrafiltration. Ultrafiltration of the supernatant of each leaf homogenate containing 30 leaves was carried out on ice through Amicon YM 10 (retention limit $10 \mathrm{kD}$ ) membranes in an Amicon pressure filtration cell at a pressure of $450 \mathrm{kPa}$. The filtrate containing compounds $\leq 10 \mathrm{kD}$ and the sediment remaining on the filter membrane (substances $\geq 10 \mathrm{kD}$ ) were lyophilized.

Gel filtration. Aliquots of dried ultrafiltrate were redissolved in an appropriate volume of distilled water to obtain a concentration of $13 \mathrm{mg} \mathrm{ml}^{-1}$ (a typical sample size was $130 \mathrm{mg}$ lyophilized ultrafiltrate in $10 \mathrm{ml}$ distilled water) and subjected to gel filtration on a Sephadex G 25 column (Pharmacia, exclusion limit $5 \mathrm{kD}$, size $2.5 \times$ $49 \mathrm{~cm}$ ). The column was calibrated with Blue Dextran and standardized with Vitamin B12 (1.3 kD), Aprotinin $(6.5 \mathrm{kD})$, and Cytochrom C (12.4 kD). Equipment used was from LKB: 2132 Microperpex Peristaltic Pump (flow rate $1.3 \mathrm{ml} \mathrm{min}^{-1}$ ), 2238 Uvicord S II spectrophotometer, 2111 Multirac fraction collector, and a 2210 2 Channel-Recorder. Samples were eluted with distilled water and collected in aliquots of $4.3 \mathrm{ml}$. The eluate was pooled into 3 fractions and lyophilized.

HPLC. Samples of $0.5 \mathrm{mg}$ of the dried gel filtration fractions were re-dissolved in $0.5 \mathrm{ml}$ distilled water and separated by HPLC on a Sephasil C 18 reversed phase column (Pharmacia, size $4.6 \times 100 \mathrm{~mm}$ ). The sample was eluted with $24 \%$ methanol at a flow rate of $0.25 \mathrm{ml} \mathrm{min}^{-1}$. A LKB 2152 HPLC Controller and 2 LKB 2150 HPLC pumps were used in addition to the equipment mentioned above. Fractions resulting from HPLC separation were pooled and freeze-dried.

Mass spectrometry. The molecular weight of the fraction that contained the highest biological activity after HPLC purification was determined using matrixassisted laser desorption ionization (MALDI) mass spectrometry (LDI-1700 Mass Monitor, Linear Scientific). The sample was dissolved in $50 \mu \mathrm{HPLC}$ quality water. For mass spectrometry $1 \mu$ of the sample was added to $10 \mu l$ of the matrix (sinapinic acid). Peak detection was carried out with a 15 pt S-G filter at a laser energy of $16.57 \mu \mathrm{J}$ and a vacuum of $1.1 \times 10^{-5}$ torr. A mass filter of $200 \mathrm{D}$ was used. The voltage of the detector was $-4.8 \mathrm{kV}$. Polarity was positive.

Amino acid analysis. Aliqouts of $0.5 \mu \mathrm{g}$ of the most bioactive HPLC fraction were subjected to acid hydrolysis with $6 \mathrm{~N} \mathrm{HCl}$. Automated amino acid analysis was then carried out with equipment from Applied Biosystems: 420 A Derivatizer, 130 A Separation System and ABI 920 A Data Analysis Module. The Procise Protein Sequencing System was used to obtain sequence data of the sample.

Biological assays. Each purification step was followed by a test for metamorphic induction. The lyophilized fractions resulting from ultrafiltration and the G 25 gel filtration pools were tested in concentrations ranging from $250 \mu \mathrm{g}$ to $5 \mathrm{mg}$ freeze-dried material $\mathrm{ml}^{-1}$ ABS in 24 well tissue culture plates. Freeze-dried HPLC fractions were assayed in $100 \mu$ l aliquots of stock solutions with concentrations of $0.5 \mathrm{mg} \mathrm{ml}^{-1} \mathrm{ABS}$ or $0.9 \mathrm{mg} \mathrm{ml}^{-1}$ ABS in microtiter plates. A defined number of larvae of Cassiopea xamachana ranging from at least 10 to maximally 15 was used per concentration. The number of planulae settled and metamorphosed was screened after 24,48 , and $72 \mathrm{~h}$. At least 6 replicates were performed per concentration. As a control, larvae were exposed in $1 \mathrm{ml}$ of ABS (at least 12 replicates). The assays were performed at a constant temperature of $25^{\circ} \mathrm{C}$ at a $12 \mathrm{~h}$ light: $12 \mathrm{~h}$ dark cycle.

Additional control experiment. Twenty-five red, recently fallen leaves of Rhizophora mangle were homogenized in $70 \mathrm{ml}$ ice-cold distilled water and subjected to the same purification procedure as described above for degrading mangrove leaves (homogenization, ultrafiltration, gel filtration and HPLC). Again each purification step was accompanied by a biological assay as described above to check on the capacity of the obtained fractions to induce metamorphosis of planula larvae of Cassiopea xamachana. Various concentrations were tested, each in at least 2 replicates.

Statistics. Metamorphosis data were subjected to statistical analysis using 1-way ANOVA followed by the Bonferroni test to establish the significance. Data were considered significant at $p<0.05$

\section{RESULTS}

\section{Leaf fractions ranging from 5 to $10 \mathrm{kD}$ induce metamorphosis}

Ultrafiltration of the supernatant of black leaf homogenate resulted in 2 crude fractions: one containing molecules $\leq 10 \mathrm{kD}$ (filtrate, total amount $4.22 \mathrm{~g}$ ) and the other one containing the substances $\geq 10 \mathrm{kD}$ (sediment 


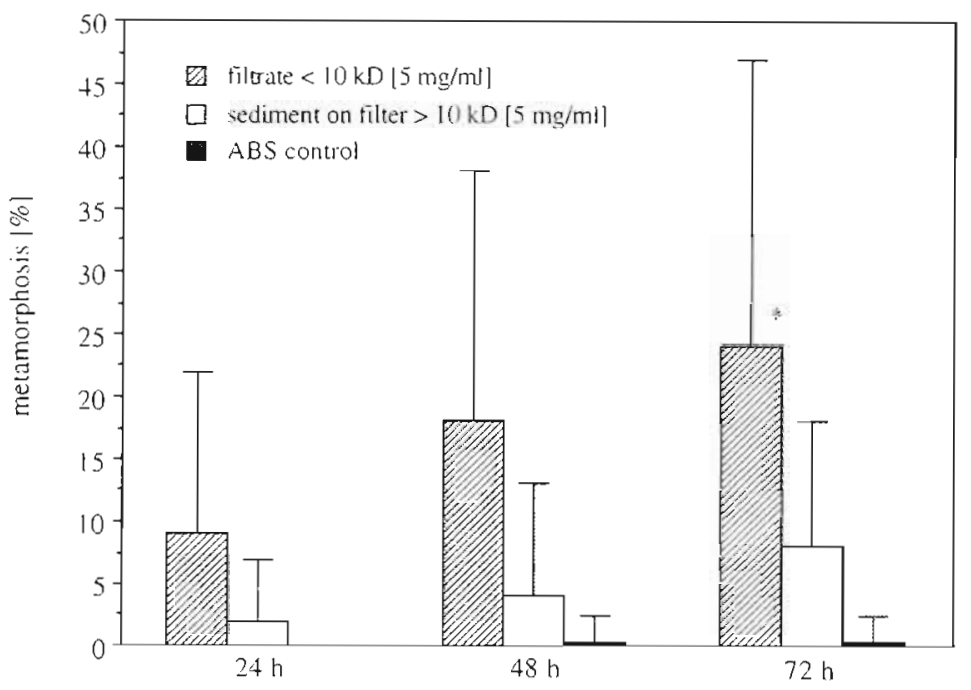

Fig. 1. Induction of metamorphosis of planula larvae of Cassiopea xamachana by fractions $\leq 10$ and $\geq 10 \mathrm{kD}$ resulting from ultrafiltration of the supernatant of homogenate of degrading Rhizophora mangle leaves. Columns show means \pm SD of 12 replicates. No column $=0 \%$ metamorphosis. *Significantly different $(p<0.05)$ from antibiotics (ABS) control

on filter, total amount $0.87 \mathrm{~g}$ ). Biological tests revealed that the filtrate induced metamorphosis of up to $24 \pm$ $23 \%$ of larvae of Cassiopea xamachana within $72 \mathrm{~h}$ (Fig. 1). However, the concentration used was high (5 $\mathrm{mg} \mathrm{m}^{-1}$ ) and the rate of metamorphosis turned out to be quite variable (Fig. 1). Likewise, settled and metamorphosed planulae were often deformed and did not develop tentacles thus indicating that-as a consequence of the homogenization procedure-the ultrafiltrate contained not only metamorphic inducers but also compounds that had a toxic effect on the larvae. This was in accordance with observations made in bioassays with synthetic peptides and pharmaceuticals that did not have any metamorphic effect on the planulae but showed such strong toxic impact in higher concentrations that the larvae were deformed and only metamorphosed in low numbers even though highly potent peptide inducers were simultaneously present in the test solutions that normally would have induced $100 \%$ settlement and metamorphosis within a few hours (Fleck unpubl.). The lowest concentration tested (250 $\mathrm{\mu g} \mathrm{m} \mathrm{g} \mathrm{m}^{-1}$ ) effected metamorphosis at a non-significant rate of $8 \pm 13 \%$. The sediment remaining on the filter triggered metamorphosis up to $9 \pm 10 \%$ of larvae at $5 \mathrm{mg} \mathrm{ml}^{-1}$ after $72 \mathrm{~h}$ but this rate was not significantly different from the ABS control (Fig. 1).

Application of the filtrate to a Sephadex G 25 column resulted in a typical profile shown in Fig. 2. The eluate was divided into 3 fractions. Fraction I contained compounds $\geq 5 \mathrm{kD}$ (Fig. 2). The pool with substances $\leq 5 \mathrm{kD}$ was divided into 2 subfractions: Fraction II and Fraction III (Fig. 2). Fraction I, which was eluted from the column at a total amount of $49.6 \mathrm{mg}$, proved to be a
O. D. 280

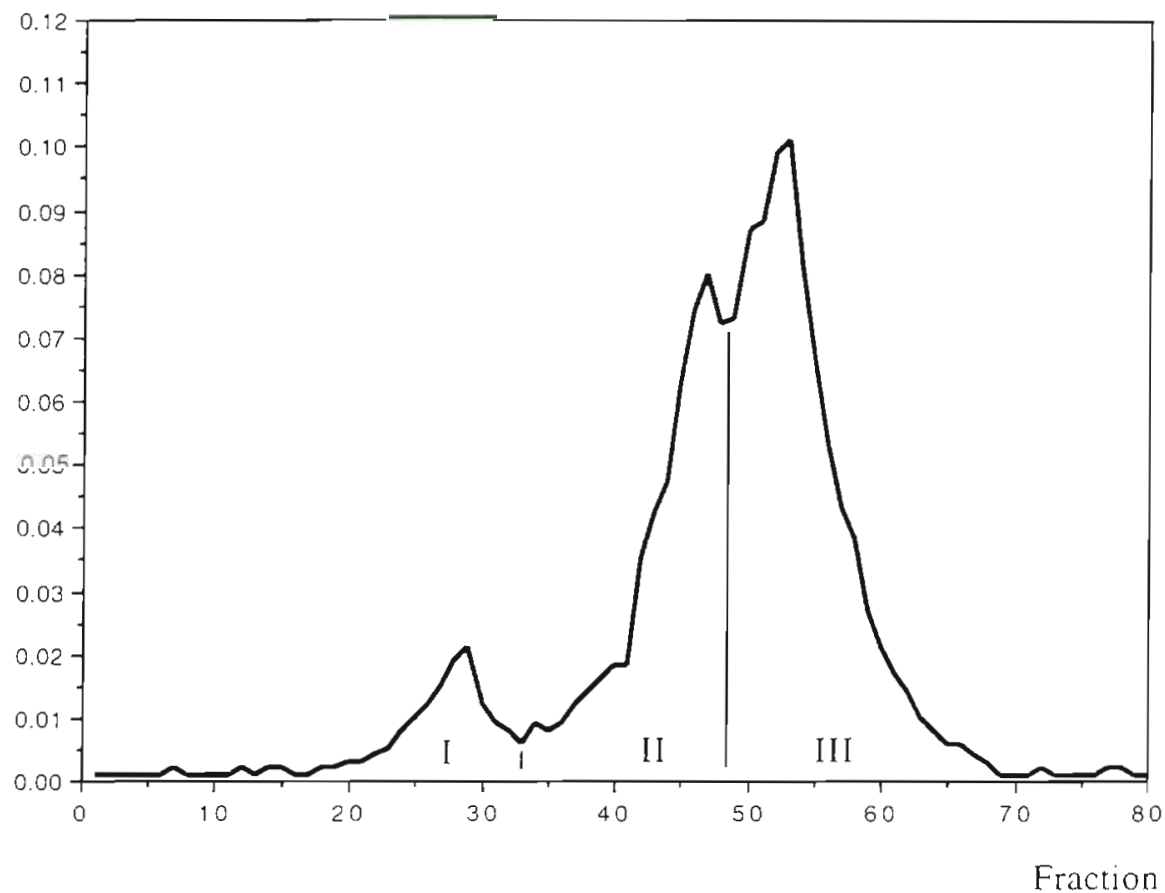

Fig. 2. Representative chromatogram of the separation of ultrafiltrate $(\leq 10 \mathrm{kD})$ of the supernatant of homogenized, degrading mangrove leaves of Rhizophora mangle on a Sephadex G 25 column. Fraction I contains compounds $\geq 5 \mathrm{kD}$, Fractions II and III $\leq 5 \mathrm{kD}$ 


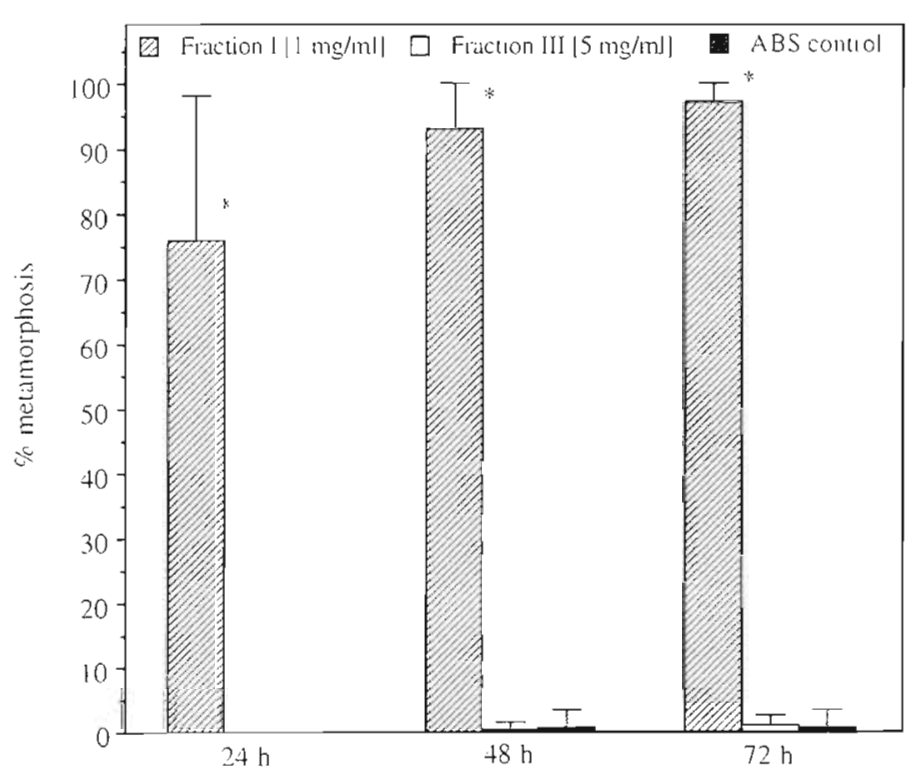

Fig. 3. Induction of metamorphosis of planula larvae of Cassiopea xamachana by Fraction $\mathrm{I}(\geq 5 \mathrm{kD})$ and Fraction III $(\leq 5 \mathrm{kD})$ resulting from gel filtration (see Fig. 2 ) of the ultrafiltrate $(\leq 10 \mathrm{kD})$ of the supernatant of homogenized, degrading leaves of Rhizophora mangle. Columns represent means \pm SD of various replicates $(n=7$ for Fraction I, $n=6$ for Fraction III, $n=12$ for ABS control). No column $=0 \%$ metamorphosis. ${ }^{*}$ Significantly different $(p<0.05)$ from ABS control

potent inducer of metamorphosis. In this instance, $75 \pm$ $22 \%$ of the larvae settled and metamorphosed within $24 \mathrm{~h}$ when exposed to this fraction at $1 \mathrm{mg}$ lyophilized material ml ${ }^{-1}$ ABS (Fig. 3). This rate increased to $97 \pm$ $8 \%$ after 72 h (Fig. 3). The polyps looked healthy and developed normal tentacles. A concentration of $250 \mu \mathrm{g}$ $\mathrm{ml}^{-1}$ induced only $21 \pm 20 \%$ metamorphosis within $72 \mathrm{~h}$. Fraction II was inactive whereas fraction III triggered metamorphosis up to only $1 \pm 3 \%$ at $5 \mathrm{mg} \mathrm{ml}^{-1}$ within 72 h (Fig. 3). Larvae were partly deformed when these fractions were applied at $5 \mathrm{mg} \mathrm{ml}^{-1}$. The results of the bioassays with Fractions II and III support the abovementioned hypothesis that the biological activity of Fraction I was counteracted by toxic, low molecular weight compounds in the ultrafiltrate.

\section{HPLC separation of the metamorphosis inducing fraction}

Fraction I was applied to reversed phase HPLC for further purification. The best resolution of the peaks that contained metamorphosis inducing capacity was obtained with isochratic elution of the column with $24 \%$ methanol. Gradient elution of the column with 0 to $100 \%$ methanol provided poorer separation of the bioactive peaks. Three peaks resulted from constant elution with $24 \%$ methanol: A, B and C (Fig. 4). Peak A was not completely separated from Peak B (Fig. 4). Elution of the column with $100 \%$ methanol following isochratic elution with $24 \%$ methanol produced an additional 15 peaks but none of the corresponding fractions proved to contain metamorphic inducers.

The total amount of the freeze-dried powder of the fractions represented by Peak A/B and Peak C was determined with an analytical balance and found to be $13.6 \mathrm{mg}$ for Fraction $\mathrm{A} / \mathrm{B}$ and $5.1 \mathrm{mg}$ for Fraction $C$. In order to perform the bioassays parts of both fractions were resuspended in ABS to obtain stock solutions with concentrations of $0.9 \mathrm{mg}$ lyophilisate $\mathrm{ml}^{-1} \mathrm{ABS}$ (Fraction $\mathrm{A} / \mathrm{B}$ ) or $0.5 \mathrm{mg}$ lyophilisate $\mathrm{ml}^{-1}$ ABS (Fraction C). Freezedried powder of Fraction $C$ induced $85 \pm 17 \%$ metamorphosis when applied at $0.5 \mathrm{mg} \mathrm{ml}^{-1}$ within $24 \mathrm{~h}$, and lyophilisate of Fraction A/B $47 \pm$ $24 \%$ (at $0.9 \mathrm{mg} \mathrm{ml}^{-1} ;$ Fig. 5). This rate increased to $89 \pm 13 \%$ for Fraction C and to $68 \pm 28 \%$ for Fraction A/B after $72 \mathrm{~h}$ (Fig. 5). Other concentrations were not tested due to the limited amount of material of the biologically active fractions. Since Peaks A and B were not completely separated, we chose to continue chracterization of only Peak $\mathrm{C}$.

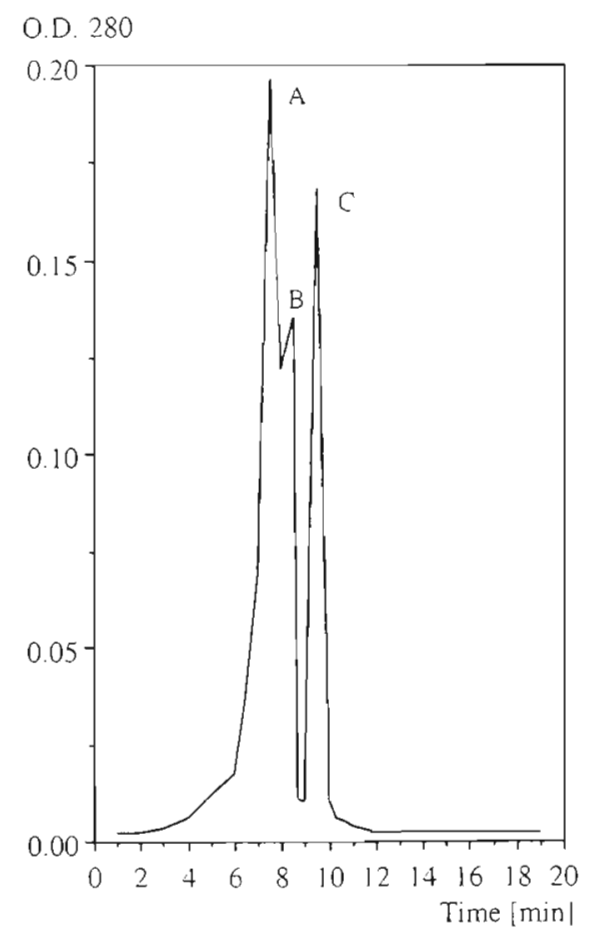

Fig. 4. Representative HPLC chromatogram of the separation of Fraction I ( $\geq 5 \mathrm{kD}$ ) obtained by gel filtration of the ultrafiltrate $(\leq 10 \mathrm{kD})$ of the supernatant of homogenized, degrading leaves of Rhizophora mangle on a reversed phase column (Sephasil C 18, constant elution with $24 \%$ methanol). Two fractions emerged: Fraction $A / B$, consisting of at least 2 subfractions, and Fraction $C$ 


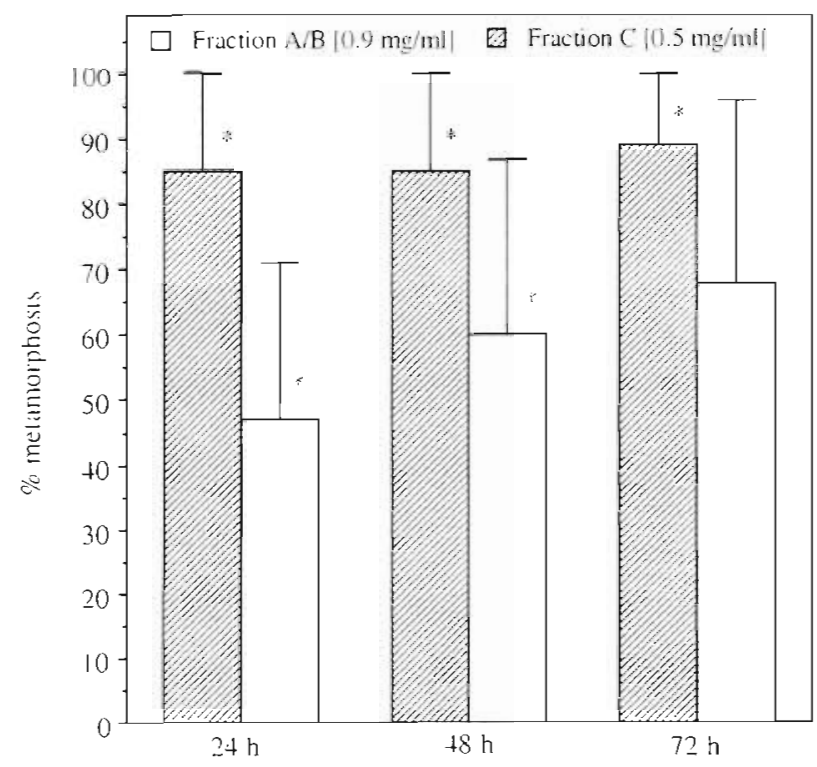

Fig. 5. Induction of metamorphosis by Fraction A/B and Fraction $C$ resulting from HPLC separation of gel filtration Fraction I (see Fig. 4). Columns show means \pm SD of 6 replicates No metamorphosis was induced by the ABS control $(\mathrm{n}=12)$.

${ }^{*}$ Significantly different $(p<0.05)$ from ABS control

\section{Characterization of Peak C}

MALDI mass spectrometry of Peak $C$, representing the most potent natural inducer purified from degrading mangrove leaves, revealed a molecular weight of exactly 5783.1 D (Fig. 6).

Amino acid analysis showed that Peak C contained a peptide that was rich in proline. This peptide mainly consisted of 26.2 proline residues, followed by 9.7 glycine residues and 5.8 glutamic acid residues (Fig. 7). Chemical sequence analysis, starting with the first amino terminal amino acid, failed in 6 independent samples of the natural cue indicating that the amino end of the peptide was blocked.

Fraction $\mathrm{A} / \mathrm{B}$ which consisted of a mixture of at least 2 compounds was not further analyzed but our previous work (Fleck \& Fitt 1999) makes it very likely that this fraction likewise contained bioactive peptides.

\section{Non-degraded leaves do not contain biologically active compounds}

None of the fractions prepared from red, more recently fallen mangrove leaves induced metamorphosis of planulae at a significant rate. Though the HPLC

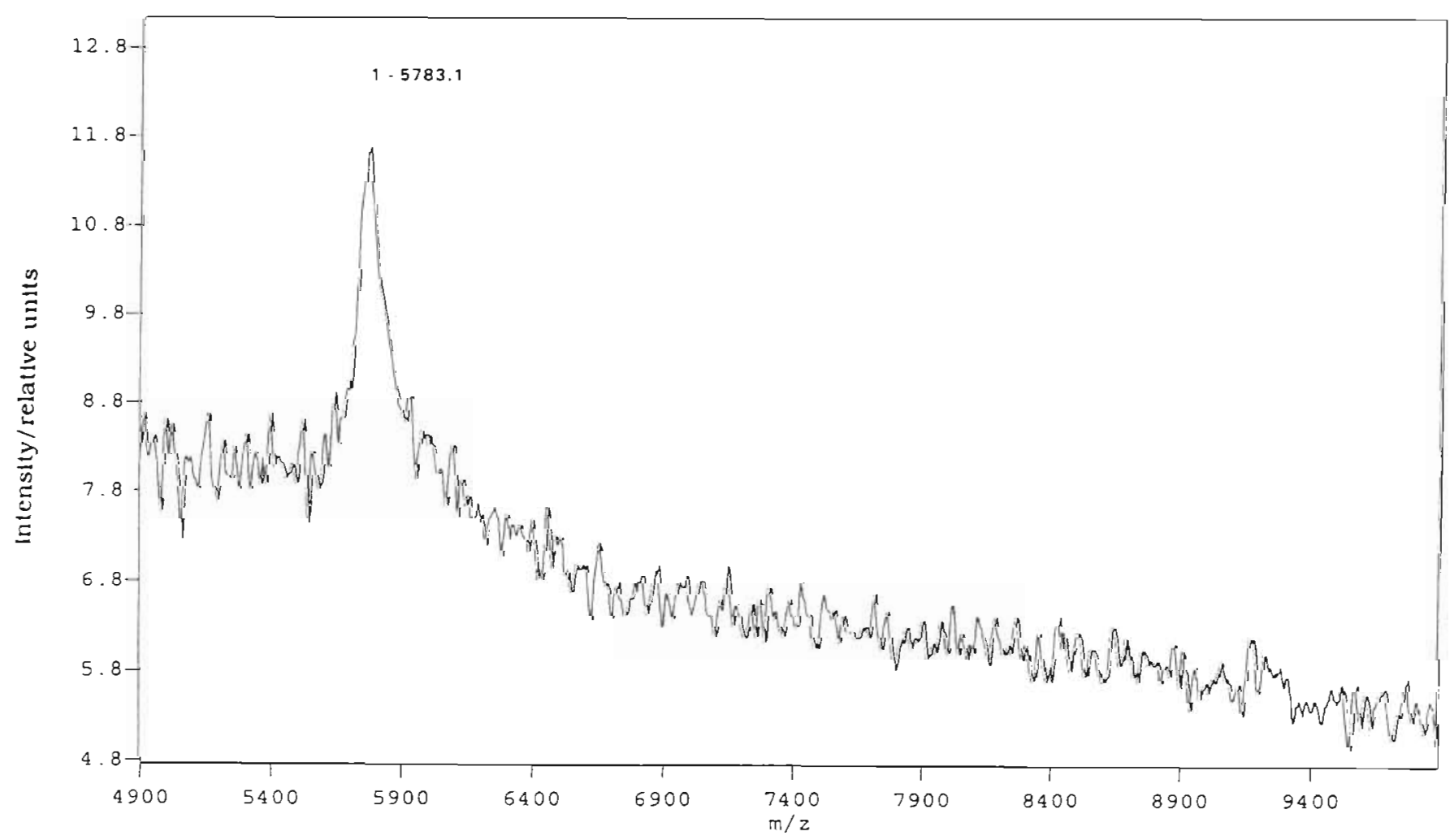

Fig. 6. Mass spectrum of HPLC Fraction C. Sum of 16 shots. For details see text 


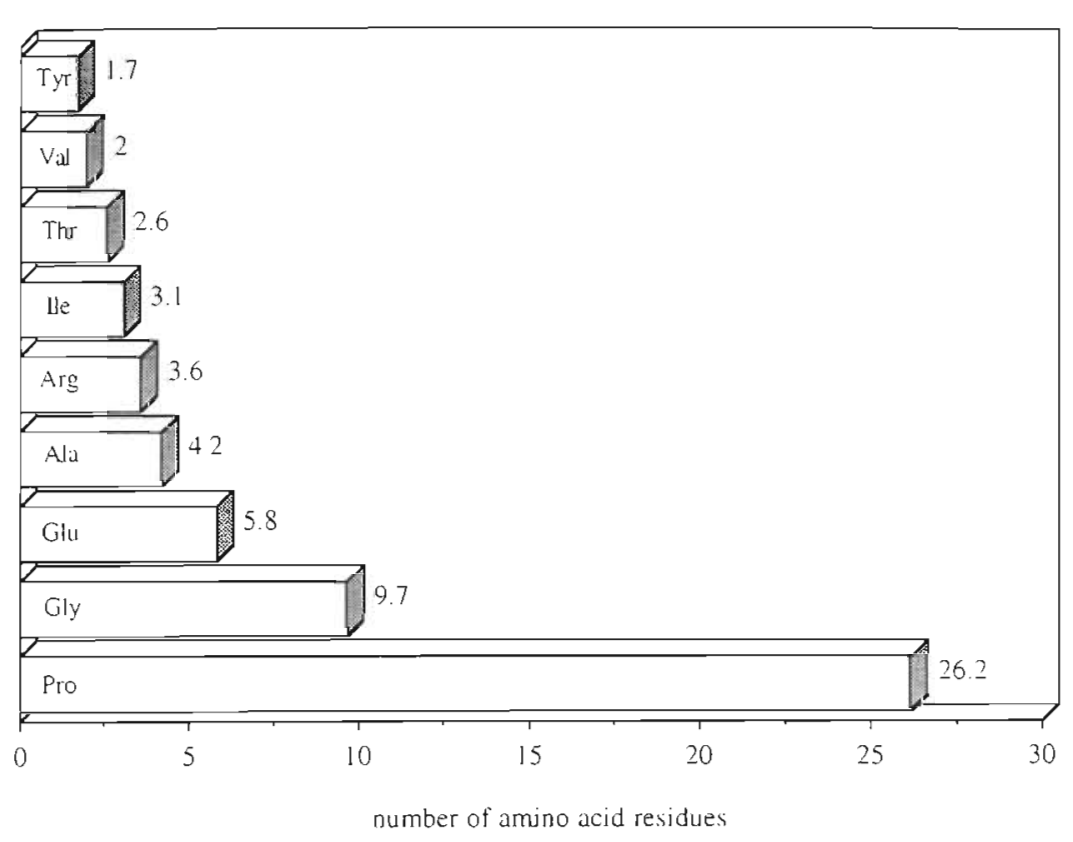

Fig. 7. Amino acid composition of one natural metamorphic cue (molecular weight $5.8 \mathrm{kD}$ ) of Cassiopea xamachana originating from degrading mangrove leaves of Rhizophora mangle. The analyzed inducer corresponds to Fraction $\mathrm{C}$ of the HPLC chromatogram (see Fig. 4)

peak pattern of a sample of the gel filtration fraction $\geq 5 \mathrm{kD}$ of red leaf ultrafiltrate $(\leq 10 \mathrm{kD})$ was similar to that of degrading leaves (Fig. 4) when eluted with $24 \%$ methanol no significant metamorphic induction of planula larvae of Cassiopea xamachana was obtained. Concentrations tested corresponded to those of Fraction $\mathrm{A} / \mathrm{B}$ and Fraction $\mathrm{C}$ of the decomposing leaves (Fig. 5). Red mangrove leaves are rarely settled by polyps in the habitat and effected settlement and metamorphosis at non-significant rates when tested in the laboratory (Fitt \& Costley 1998, Fleck \& Fitt 1999).

\section{DISCUSSION}

Our study demonstrates that peptides represent at least 1 of the natural metamorphic inducers for the upside-down jellyfish Cassiopea xamachana found in degrading leaves of the red mangrove. In the present study we have isolated and characterized at least 1 peptidic cue from black, degraded mangrove leaves of Rhizophora mangle that provide 1 of the substrates settled by larvae in the mangove environment (Fitt 1991, Fitt \& Costley 1998, Fleck \& Fitt 1999). This natural inducer has a molecular weight of approximately $5.8 \mathrm{kD}$, contains about 59 amino acids and is dominated by proline and glycine residues (ca $61 \%$ in total). We have therefore confirmed that laboratory studies using peptides as metamorphic triggers, indeed mimick what occurs in na- ture (Fitt \& Hofmann 1985, Fitt et al. 1987, Hotmann \& Brand 1987, Fleck \& Hofmann 1990, 1995, Bischoff et al. 1991, Fleck \& Bischoff 1993, Hofmann et al. 1996, Fleck 1997, Fleck 1998, Walther \& Fleck 1998). Like the characterized natural cue originating from mangrove leaves, the most effective synthetic peptidic inducers were mainly composed of proline and glycine residues (Fitt \& Hofmann 1985, Hofmann \& Brand 1987, Fleck \& Hofmann 1990. Fleck \& Bischoff 1993, Hofmann et al. 1996, Walther \& Fleck 1998). We suspect that at least one other partially characterized inducer (Fraction $A / B$ ) in our study is also a peptide.

Peptides have also been found to naturally trigger metamorphosis in larvae of the sand dollar Dendraster excentricus (Burke 1984), the oyster Crassostrea virginica (Tamburri et al. 1992), the barnacle Balanus amphitrite (Tegtmeyer \& Rittschof 1989), and the nudibranch Adalaria proxima (Lambert et al. 1997). None of these studies, however, provides the exact molecular weight, the amino acid composition and/or sequence data of the natural cue. Chemical sequencing of the purified natural inducer of Cassiopea xamachana has thus far failed with the methods applied because the amino terminus was blocked by a yet unidentified group.

What is the source of the peptidic cue derived from the degrading mangrove leaves? A recent study by Fleck \& Fitt (1999) suggests that bacteria are involved in the production of natural inducers. Bacteria have been shown to take part in metamorphic induction of several marine invertebrates (see review by Johnson et al. 1997). Based on laboratory experiments dealing with bacterial cleavage of collagen, Hofmann \& Brand (1987) proposed that bacteria may provide potential inducers for metamorphosis of Cassiopea spp. by cleaving deteriorating, proteinaceous cues in the ocean. Our study strongly indicates that degrading mangrove leaves may represent such suitable cues. Proline-rich proteins (PRPs) consisting of amino acid compositions corresponding to that of the natural metamorphic inducer of $C$. xamachana isolated from Rhizophora mangle are common elements of plant cell walls (e.g. Ye et al. 1991, Nicholas et al. 1993, Kieliszewski \& Lamport 1994, Rodriguez \& Cardemil 1994, Williamson 1994, Yu et al. 1996, Wojtaszek et al. 1997. Davies et al. 1997). Bacterial degradation of such proteins of decomposing plant tissue may therefore result in a variety of peptides, some of them containing 
a specific signal sequence enabling them to trigger not only metamorphosis of Cassiopea spp. but also of other marine invertebrate larvae. Humic acids, representing another complex mixture of compounds of degrading vegetation, accelerated metamorphosis of postlarvae of the blue crab Callinectes sapidus to the first crab stage (Forward et al. 1997).

The size of the natural peptidic cues ( 5 to $10 \mathrm{kD}$ ) is much larger than the size of the synthetic peptides used in the laboratory for metamorphosis studies in Cassiopea spp. (<1 kD). However, it has been shown that the sequence of the carboxyterminal amino acids contains the signal for classifying a peptide as biologically active, and that any peptide containing at least 3 amino acids and this particular sequence (GPA) is sufficient to trigger metamorphosis of Cassiopea spp. larvae and buds (Fitt \& Hofmann 1985, Fitt et al. 1987, Hofmann \& Brand 1987, Fleck \& Hofmann 1990, Fleck 1994, Hofmann et al. 1996, Walther \& Fleck 1998). The concentration of the $5.8 \mathrm{kD}$ natural cue which was used in this study to induce metamorphosis of a high percentage of larvae $\left(8.6 \times 10^{-5} \mathrm{~mol} \mathrm{l}^{-1}\right)$ was higher than the lowest concentration needed to effect $100 \%$ metamorphosis within $24 \mathrm{~h}$ with the most potent synthetic peptide (Dabsyl-GPGGPA, 2.0 to $3.4 \times 10^{-6} \mathrm{~mol} \mathrm{l}^{-1}$ for larvae and buds, Hofmann et al. 1996). However, other concentrations of the natural inducer were not tested due to the limited amount of material though the concentration applied was still in the concentration range of other highly potent synthetic peptide inducers $(1.3$ to $9.4 \times 10^{-5} \mathrm{~mol} \mathrm{l}^{-1}$; Fleck 1994, Hofmann et al. 1996 , Walther \& Fleck 1998). The natural cue for larval metamorphosis of the sand dollar Dendraster excentricus also had to be applied at concentrations between $10^{-6}$ and $10^{-5} \mathrm{~mol} \mathrm{l}^{-1}$ in order to effect about $60 \%$ metamorphosis (Burke 1984). In fact, larvae of C. xamachana are thought to require a relatively higher concentration of inducers since the larger adults of this species of jellyfish appear to need high levels of nutrients to supplement lack of carbon transferred from their symbiotic dinoflagellates (Vodenichar 1995)

Bacterial degradation of mangrove leaf cell wall proteins results in more than 1 peptide containing the signal sequence for metamorphic induction. This was also indicated by the results of the bioassays with the sediment $(\geq 10 \mathrm{kD}$ ) on the filter after ultrafiltration and with Fraction III $(\leq 5 \mathrm{kD}$ ) obtained from gel filtration of the supernatant of leaf homogenate in this study. Though the percentage of metamorphosis triggered by these fractions was low $19 \%$ for compounds $\geq 10 \mathrm{kD}$. Fig. $1 ; 1 \%$ for Fraction III molecules $\leq 5 \mathrm{kD}$, Fig. 3) we cannot exclude the possibility that potential inducers were contaminated with toxic substances in the same molecular weight range released by the homogenization procedure that might counteract any significant bioactivity. Therefore a multitude of peptidic inducers originating from mangrove leaves may act together thereby inducing metamorphosis of planulae at lower and environmentally more relevant concentrations of each single peptide compared to the relatively high concentration necessary for 1 single inducer, e.g. Fraction $C$ resulting from HPLC in the present study, which likewise may be subject to further bacterial degradation in nature. Laboratory experiments carried out with optimal concentrations $(100 \%$ metamorphosis within $24 \mathrm{~h}$ ) of single synthetic peptide inducers and mixtures of suboptimal concentrations ( 0 to $50 \%$ metamorphosis within $24 \mathrm{~h}$ ) of biologically active peptides support this hypothesis (Fleck unpubl.). Likewise, degrading Rhizophora mangle leaves are often settled by only a few polyps of Cassiopea xamachana in the habitat though possibly exposed to thousands of larvae. This implies that suboptimal concentrations of the inducers could trigger settlement and metamorphosis at a rate that is sufficient enough to ensure reproduction of the species in organically and nutrient-rich mangrove habitats. Similarly, localized production of high concentrations of the cue on the surface of degrading mangrove leaves by proteolysis by isolated bacterial colonies on the leaf surface may also explain the sparce or clumped distribution of natural larval settlement.

At present we cannot exclude that the natural metamorphic cues originate from bacteria exclusively, e.g. decaying mangrove leaves may provide a substrate for specific bacteria that produce the cues as part of their exopolymeric coating. However, the fact that (1) the amino acid composition of the peptide isolated in this study corresponds to that of proline-rich cell wall proteins of plants, (2) HPLC purification of leaf homogenate of red, less-degraded leaves of Rhizophora mangle that should have been also settled by bacteria (Cuba \& Blake 1983) did not trigger metamorphosis (present study) and (3) debris removed from the surface of degrading leaves did not alter metamorphic induction (unpubl. results), strongly suggest that the mangrove leaves need to reach a certain state of degradation before bacteria can use their cell wall proteins as a substrate in order to produce and/or modify specific fragments of peptides including the natural metamorphic cues for Cassiopea xamachana.

Our present study provides evidence that at least 1 HPLC purified fraction of homogenate of decaying mangrove leaves originating from the habitat of Cassiopea xamachana contained a peptide that effected settlement and metamorphosis of its planula larvae in laboratory bioassays, thus indicating that peptides represent the primary stimulus for metamorphic induction not only in the laboratory, but also in nature. The results of our study are also consistent with the hypothesis that settlement and metamorphosis may be nonspecific, not relying on only 1 single specific inducer 
molecule (Fleck 1994). Thus we conclude that natural metamorphic cues for Cassiopea spp. may emerge from bacterial degradation of proteinaceous tissue of plants assuring recruitment into nutrient-rich habitats where juveniles are likely to grow and strobilate into reproductively active adults.

Acknowledgements. We thank Steve Miller, University of North Carolina at Wilmington, and the National Undersea Research Center on Key Largo, Florida, for providing lab space and nitrogen for the ultrafiltration. The introduction to mass spectrometry by Ron Orlando and his group from the Complex Carbohydrate Research Center, University of Georgia, Athens, Georgia, is gratefully acknowledged. Thanks are also due to Barbara Potempa, now at the University of Krakow, Poland, for helping us to determine the amino acid composition and the sequence of the isolated cue and to D. K. Hofmann for his continuing advice and support. We are grateful for the useful comments of 4 anonymous reviewers. A Feodor-Lynen-fellowship from the Alexander von HumboldtStiftung, Bonn, Germany, to J.F. provided the basis for this cooperative research. Contribution No. 011 from the Key Largo Marine Research Laboratory.

\section{LITERATURE CITED}

Avila C (1998) Competence and metamorphosis in the longterm planktotrophic larvae of the nudibranch mollusc Hermissenda crassicornis (Eschscholtz, 1831). J Exp Mar Biol Ecol 231:81-117

Berking $S$ (1998) Hydrozoa metamorphosis and pattern formation. Curr Top Dev Biol 38:81-131

Bischoff A, Fleck J, Hofmann DK (1991) Phorbol esters induce metamorphosis in Cassiopea andromeda and Cassiopea xamachana (Cnidaria, Scyphozoa). Verh Dtsch Zool Ges $84: 484$

Burke R (1984) Pheromonal control of metamorphosis in the Pacific sand dollar, Dendraster excentricus. Science 225: $442-443$

Carpizo-Ituarte E, Hadfield MG (1998) Stimulation of metamorphosis in the polychaete Hydroides elegans Haswell (Serpulidae). Biol Bull 194:14-24

Cuba TR, Blake NJ (1983) The initial development of marine fouling assemblage on a natural substrate in a subtropical estuary. Bot Mar 26:259-264

Davies HA, Findlay K, Daniels MJ, Dow JM (1997) A novel proline-rich glycoprotein associated with the extracellular matrix of vascular bundles of Brassica petioles. Planta 202:28-35

Fitt WK (1991) Natural metamorphic cues of larvae of a tropical jellyfish. Am Zool 31:106

Fitt WK, Costley K (1998) The role of temperature in survival of the polyp stage of the tropical rhizostome jellyfish Cassiopea xamachana. J Exp Mar Biol Ecol 222:79-91

Fitt WK, Hofmann DK (1985) Chemical induction of settlement and metamorphosis of the reef-dwelling coelenterate Cassiopea andromeda. Proc 5th Int Coral Reef Symp 2:239--244

Fitt WK, Hofmann DK, Wolk M, Rahat M (1987) Requirement of exogenous inducers for metamorphosis of axenic larvae and buds of Cassiopea andromeda (Cnidaria: Scyphozoa). Mar Biol 94:415-422

Fleck J (1994) Efficiency of modified inducing peptides, possible signal transduction mechanism and chemical fate of a biologically active peptide in induction of metamorphosis in Cassiopea spp. (Cnidaria, Scyphozoa). PhD thesis,
Ruhr-Universität Bochum, Bochum (in German with English summary)

Fleck J (1997) Phosphatidylinositol (PI) signaling and subsequent events in metamorphosis induction of cnidarian larvae. Proc 8th Int Coral Reef Symp 2:1225-1229

Fleck J (1998) Chemical fate of a metamorphic inducer in larvae-like buds of the cnidarian Cassiopea andromeda. Biol Bull 194:83-91

Fleck J, Bischoff A (1993) Protein kinase C is possibly involved in chemical induction of metamorphosis in Cassiopea spp. (Cnidaria: Scyphozoa). Proc 7th Int Coral Reef Symp 1:456-462

Fleck J, Fitt WK (1999) Degrading mangrove leaves of Rhizophora mangle provide a natural metamorphic cue for the upside down jellyfish Cassiopea xamachana. J Exp Mar Biol Ecol 234:83-94

Fleck J, Hofmann DK (1990) The efficiency of metamorphosis inducing oligopeptides in Cassiopea species (Cnidaria: Scyphozoaj depends on both primary structure and amino- and carboxy terminal substituents. Verh Dtsch Zool Ges 83:452-453

Fleck J, Hofmann DK (1995) In vivo binding of a biologically active oligopeptide in vegetative buds of the scyphozoan Cassiopea andromeda: demonstration of receptor-mediated induction of metamorphosis. Mar Biol 122:447-451

Forward RB Jr, DeVries MC, Rittschof D, Frankel DAZ, Bischoff JP, Fisher CM, Welch JM (1996) Effects of environmental cues on metamorphosis of the blue crab Callinectes sapidus. Mar Ecol Prog Ser 131:165-177

Forward RB Jr, Tankersley RA, Blondel D, Rittschof D (1997) Metamorphosis of the blue crab Callinectes sapidus: effects of humic acids and ammonium. Mar Ecol Prog Ser $157: 277-286$

Froggett SJ, Leise EM (1999) Metamorphosis in the marine snail Ilyanassa obsoleta, yes or NO? Biol Bull 196:57-62

Gibson G (1995) Why be choosy? Temporal changes in larval sensitivity to several naturally-occuring metamorphic inducers in the opisthobranch Haminaea callidegenita. J Exp Mar Biol Ecol 194:9-24

Hadfield MG, Pennington JT (1990) Nature of the metamorphic signal and its internal transduction in larvae of the nudibranch Phestilla sibogae. Bull Mar Sci 46:455-464

Hassel M, Leitz T, Müller WA (1996) Signals and signal-transduction systems in the control of development in Hydra and Hydractinia. Int J Dev Biol 40:323-330

Henning G, Hofmann DK, Benayahu Y (1996) The phorbol ester TPA induces metamorphosis in Red Sea coral planulae (Cnidaria: Anthozoa). Experientia 52:744-749

Hofmann DK, Brand U (1987) Induction of metamorphosis in the symbiotic scyphozoan Cassiopea andromeda: role of marine bacteria and of biochemicals. Symbiosis 4:99-116

Hofmann DK, Neumann R, Henne K (1978) Strobilation, budding and initiation of scyphistoma morphogenesis in the rhizostome Cassiopea andromeda (Cnidaria: Scyphozoa). Mar Biol 47:161-176

Hofmann DK, Fitt WK, Fleck J (1996) Checkpoints in the lifecycle of Cassiopea andromeda: control of metagenesis and metamorphosis in a tropical jellyfish. Int $\mathrm{J}$ Dev Biol 40 : $331-338$

Jaccarini V, Agius L, Schembri PJ, Rizzo M (1983) Sex determination and larval sexual interaction in Bonellia viridis Rolando (Echiura: Bonelliidae). J Exp Mar Biol Ecol 66: $25-40$

Jensen RA, Morse DE (1984) Intraspecific facilitation of larval recruitment: gregarious settlement of the polychaete Phragmatopoma californica (Fewkes). J Exp Mar Biol Ecol $83: 107-126$ 
Jensen RA, Morse DE (1990) Chemically induced metamorphosis of polychaete larvae in both the laboratory and ocean environment. J Chem Ecol 16:911-930

Jensen RA, Morse DE, Petty RL, Hooker N (1990) Artificial induction of larval metamorphosis by free tatty acids. Mar Ecol Prog Ser 67:55-71

Johnson CR, Lewis DE, Nichols DS, Degnan BM (1997) Bacterial induction of settlement and metamorphosis in marine invertebrates. Proc 8th Int Coral Reef Symp 2:1219-1224

Kato $T$, Kumanireng AA, Ichinose I, Kitahara Y, Kakinuma Y, Nishihira M, Kato M (1975) Active components of Sargassum tortile effecting the settlement of swimming larvae of Coryne uchidai. Experientia 31:433-434

Kieliszewski MJ, Lamport DI (1994) Extensin: repetitive motifs, functional sites, post-translational codes, and phylogeny. Plant J 5:157-172

Lambert WJ, Todd CD, Hardege JD (1997) Partial characterization and biological activity of a metamorphic inducer of the dorid nudibranch Adalaria proxima (Gastropoda: Nudibranchia). Invertebr Biol 116:71-81

Leitz T, Wagner T (1993) The marine bacterium Alteromonas espejiana induces metamorphosis of the hydroid. Hydractinia echinata. Mar Biol 115:173-178

McCauley DW (1997) Serotonin plays an early role in the metamorphosis of the hydrozoan Phialidium gregarium. Dev Biol 190:229-240

Morse DE, Morse ANC (1991) Enzymatic characterization of the morphogen recognized by Agaricia humilis (scleractinian coral ) larvae. Biol Bull 181:104-122

Morse DE, Hooker N, Morse ANC, Jensen RA. (1988) Control of larval metamorphosis and recruitment in sympatric agariciid corals. J Exp Mar Biol Ecol 116:193-217

Müller WA (1969) Auslosung der Metamorphose durch Bakterien bei den Larven von Hydractinia echinata. Zool Jb (Abt Anat Ontog Tiere) 86:84-95

Neumann R (1979) Bacterial induction of settlement and metamorphosis in the planula larvae of Cassiopea andromeda (Cnidaria: Scyphozoa, Rhizostomeae). Mar Ecol Prog Ser 1:21-28

Nicholas CD, Lindstrom JT, Vodkin LO (1993) Variation of proline rich cell wall proteins in soybean lines with anthocyanin mutations. Plant Mol Biol 21:145-156

Nishihira M (1968) Brief experiments on the effect of algal extracts in promoting the settlement of the larvae of Coryne uchidai Stechow (Hydrozoa). Bull Mar Biol Sta Asamushi 13:91-101

Pawlik JR (1986) Chemical induction of larval settlement and metamorphosis in the reef-building tube worm Phragmatopoma californica (Polychaeta: Sabellariidae). Mar. Biol 91:59-68

Pawlik JR (1988) Larval settlement and metamorphosis of sabellariid polychaetes, with special reference to Phragmatopoma lapidosa, a reef-building species, and Sabellaria floridensis, a non-gregarious species. Bull Mar Sci 43:41-60

Pawlik JR (1992) Chemical ecology of the settlement of benthic marine invertebrates. Oceanogr Mar Biol Annu Rev 30:273-335

Pawlik JR, Faulkner DJ (1986) Specific free fatty acids induce larval settlement and metamorphosis of the reef-building tube worm Phragmatopoma californica (Fewkes). J Exp Mar Biol. Ecol 102:301-310

Pechenik JA, Qian. PY (1998) Onset and maintenance of metamorphic competence in the marine polychaete Hydroides elegans Haswell in response to three chemical cues. J Exp Mar Biol Ecol 226:51-74

Pechenik JA, Hadfield MG, Eyster S (1995) Assessing whether larvae of the opisthobranch gastropod Phestilla sibogae Bergh become responsive to three chemical cues at the same age. J Exp Mar Biol Ecol 191:1-17

Pelter A, Ballantine JA, Murray-Rust P, Ferrito V, Psaila AF (1978) The structures of anhydrobonellin and bonellin, the physiologically active pigment from the marine echiuroid Bonellia viridis. Tetrahedron Lett 21:1881-1884

Rittschof D (1993) Body odors and neutral-basic peptides mimics: a review of responses of marine organisms. Am Zool 33:487-493

Rodriguez JG, Cardemil L (1994) Cell wall proteins in seedling cotyledons of Prosopis chilensis. Phytochemistry 35: $281-286$

Tamburri MN, Zimmer-Faust RK, Tamplin ML (1992) Natural sources and properties of chemical inducers mediating settlement of oyster larvae: a re-examination. Biol Bull $183: 327-338$

Tegtmeyer K. Rittschof D (1989) Synthetic peptide analogs to barnacle settlement pheromone. Peptides 9:1403-1406

Thomas MB, Edwards NC, Ball BE, McCauley DW (1997) Comparison of metamorphic induction in hydroids. Invertebr Biol 116:277-285

Tsukamoto S, Hirota H, Kato H, Fusetani N (1993) Urochordamines A and B: larval settlement/metamorphosis-promoting, pteridine-containing physostigmine alkaloids from the tunicate Ciona savignyi. Tetrahedron Lett 34:4819-4822

Vodenichar JS (1995) Ecological physiology of the scyphozoan Cassiopea xamachana. MS thesis, University of Georgia, Athens

Walters LJ, Hadfield MG, del Carmen KA (1997) The importance of larval choice and hydrodynamics in creating aggregations of Hydroides elegans (Polychaeta: Serpulidae). Invertebr Biol 116:102-114

Walther M, Fleck J (1998) Synthetic peptides inducing metamorphosis in a tropical jellyfish: a quantitative structure-activity relationship study. Comp Biochem Physiol A 120:655-659

Walther M, Ulrich R, Kroiher M, Berking S (1996) Metamorphosis and pattern formation in Hydractinia echinata, a colonial hydroid. Int J Dev Biol 40:313-322

Wendt DE, Woollacott RM. (1995) Induction of larval settlement by $\mathrm{KCL}$ in three species of Bugula (Bryozoa). Invertebr Biol 114:345-351

Wieczorek SK, Todd CD (1997) Inhibition and facilitation of bryozoan and ascidian settlement by natural multi-species biofilms: effects of film age and the roles of active and passive larval attachment. Mar Biol 128:463-473

Williamson MP (1994) The structure and function of prolinerich regions in proteins. Biochem J 297:249-260

Wojtaszek P. Trethowan J, Bolwell GP (1997) Reconstitution in vitro of the components and conditions required for the oxidative cross-linking of extracellular proteins in French bean (Phaseolus vulgaris L.). FEBS Lett 405:95-98

Woollacott RM, Hadfield MG (1996) Induction of metamorphosis in larvae of a sponge. Invertebr Biol 115:257-262

Ye ZH, Song YR, Marcus A, Varner JE (1991) Comparative localization of three classes of cell wall proteins. Plant $J$ $1: 175-183$

Yu LX, Chamberland H, Lafontaine JG, Tabaeizadeh Z (1996) Negative regulation of gene expression of a novel proline, threonine-, and glycine-rich protein by water stress in Lycopersicon chilense. Genome 39:1185-1193

Yvin JC, Chevolot L, Chevolot-Magueur AM, Cochard JC (1985) First isolation of jacaranone from an alga, Delesseria sanguinea. A metamorphosis inducer of Pecten larvae. J Nat Prod 48:814-816

Zimmer-Faust RK, Tamburri MN (1994) Chemical identity and ecological implications of a waterborne, larval settlement cue. Limnol Oceanogr 39:1075-1087 